\begin{tabular}{|l|l|l||}
\hline \multicolumn{2}{|c|}{ PublisherInfo } \\
\hline \hline PublisherName & $:$ & BioMed Central \\
\hline \hline PublisherLocation & $:$ & London \\
\hline \hline PublisherImprintName & $:$ & BioMed Central \\
\hline \hline
\end{tabular}

\title{
UK committee backs open access
}

\begin{tabular}{|l|c|l||}
\hline \multicolumn{2}{|c|}{ ArticleInfo } \\
\hline \hline ArticleID & $:$ & 4981 \\
\hline \hline ArticleDOI & $:$ & $10.1186 /$ gb-spotlight-20040721-01 \\
\hline \hline ArticleCitationID & $:$ & spotlight-20040721-01 \\
\hline \hline ArticleSequenceNumber & $:$ & 44 \\
\hline \hline ArticleCategory & $:$ & Research news \\
\hline ArticleFirstPage & $:$ & 1 \\
\hline \hline ArticleLastPage & $:$ & 4 \\
\hline \hline & & RegistrationDate : 2004-7-21 \\
\hline ArticleHistory & $:$ & OnlineDate \\
\hline \hline ArticleCopyright & $:$ & BioMed Central Ltd2004-7-21 \\
\hline \hline ArticleGrants & $:$ & \\
\hline \hline ArticleContext & $:$ & 130595511 \\
\hline \hline
\end{tabular}




\section{Stephen Pincock}

Email: stephen@thescientisteurope.com

LONDON - Britain should insist that government-funded researchers deposit a copy of their scientific papers in an electronic archive that can be accessed for free online, an influential committee of politicians said Tuesday (July 20).

The House of Commons Science and Technology Committee has been investigating science publishing most of this year. Its deliberations drew on an ongoing debate over 'open access' to research, whose advocates say that the output from scientific research should be available free of charge.

"We have recommended that the UK government fund the establishment of an interlinked network of institutional repositories on which all research articles originating in the UK should be deposited and can be read for free," the committee's report states. "In order to ensure that the repositories are well populated, we have recommended that research councils mandate their funded researchers to deposit copies of all their articles in this way."

The committee suggests that the government should appoint a central body to oversee the implementation of repositories and help with their setting up. The UK government has to respond to the committee's report and is expected to do so within 2 months.

A spokesperson for the Biotechnology and Biological Sciences Research Council (BBSRC) told us that the council wants to encourage data to be available as readily as possible, while ensuring that the quality of scientific publications is maintained.

"BBSRC is working with its sister research councils under the coordination of Research Councils UK (RCUK) to continue to develop our policy for addressing the needs of this rapidly evolving area," the spokesperson said.

The members of the committee stop short giving their full support to open-access publishing, in which the author pays to publish instead of the reader paying a fee for access. The United Kingdom has too little experience of this model to know what effect it would have, the politicians said. Nevertheless, they recommended that the research councils make funds available so researchers can publish in such journals if they want.

Jan Velterop, publisher of BioMedCentral called the report an important milestone in the open-access movement.

"The overall report... is really a ringing endorsement of the whole concept of open access to scientific material," Velterop said. "It definitely is a major development. I even think that with hindsight, we may look back on this as a turning point."

Peter Suber, an open-access advocateat Earlham College in Richmond, Ind., said he was delighted that the report "doesn't merely endorse open access, but calls for a national commitment to open access encompassing all UK higher education institutions, the British Library, the research councils, the government funding agencies, and government policymakers." 
"The report recommends many steps, but properly focuses on the one step that will do the most good: asking government funding agencies to put an open-access condition on research grants and requiring grantees to deposit the full-text articles based on funded research in open-access repositories," Suber told us.

Most scientific research is currently published in journals that charge for access, although many allow their authors to self-archive papers. In June, Elsevier, one of the biggest science publishers, made this move.

But this week, Arie Jongejan, chief executive officer of Science and Technology for Elsevier, said some of the concerns expressed in the report about government policy were overstated. "We are doubtful that the government will necessarily agree to recommendations made by the report," he said.

The committee also urged the United Kingdom to take an international role as a proponent for change in scientific publishing. In response, Graham Taylor, director of Academic Publishing at the Publishers Association, said the UK industry was already a center of excellence for scientific publishing. "We look forward to engaging with government and its agencies on the issues that the committee has raised in order to ensure an efficient and sustainable strategy for the future," he said.

Just last week, the US House of Representatives Appropriations Committee also recommended that the National Institutes for Health (NIH) make research it funds freely available.

In a report, the committee called on NIH to offer access to authors' final manuscripts and supplemental materials via PubMed Central 6 months after publication. If the grantee used NIH funds to pay any publication charges, free access would be immediate.

Taken together, these political recommendations suggest an international consensus is growing in support of open access, said Michael B. Eisen, cofounder of open-access publisher Public Library of Science.

"The report from the House of Commons committee and the bill passed by the US House committee are a call to action. Both have made clear the need for better access to publicly funded scientific works, and both have offered concrete mechanisms for achieving it," Eisen said in a statement.

\section{References}

1. Science and Technology Committee, [http://www.parliament.uk/parliamentary_committees/ science_and_technology_committee.cfm]

2. Brahic C: UK hears open access evidence The Scientist, March 10, 2004., [http://www.thescientist.com/news/20040310/05/] 
3. Research Councils UK, [http://www.rcuk.ac.uk]

4. McCook A: Open-access journals rank well The Scientist, April 27, 2004., [http://www.thescientist.com/news/20040427/05/]

5. "Elsevier further liberalizes copyright for authors," Elsevier company news, June 3, 2004., [http://www.elsevier.com/wps/find/authored_newsitem.cws_home/companynews05_00145]

6. PubMed Central, [http://www.pubmedcentral.nih.gov/] 